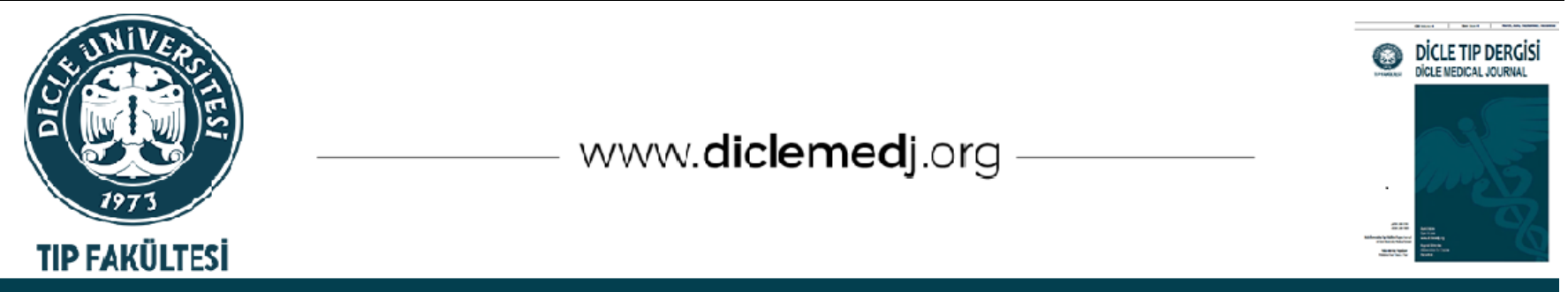

Original Article / Özgün Araştırma

\title{
Investigation of Dentists' Opinions on Pharmacovigilance and Reporting of Adverse Effects
}

\author{
Zeynep Erdogmus Ozgen ${ }^{1}{ }_{1}$, Zozan Erdogmus ${ }^{i}{ }_{2}$ \\ 1 Department of Pharmacology, School of Pharmacy, Dicle University, Diyarbakir, Turkey \\ 2 Ministry of Health, Diyarbakir Oral and Dental Health Hospital, Diyarbakır, Turkey \\ Received: 13.09.2021; Revised: 07.11.2021; Accepted: 10.11.2021
}

\begin{abstract}
Objective: In this study, it was aimed to examine the experience, knowledge, and awareness of dentists about adverse drug effects and pharmacovigilance.

Methods: In this cross-sectional and descriptive study, a 15-question questionnaire was applied to 100 dentists who are working at Diyarbakir Oral and Dental Health Hospital to evaluate their knowledge, attitudes and practices about adverse effects and pharmacovigilance.

Results: 55 percent of dentists stated that they had never encountered an adverse drug reaction (ADR) in their professional life. Even though 45 percent of them reported that they have rarely seen ADR in their professional life, the total number of declarations has been determined as $7.78 \%$ of dentists are aware that declaration is required and this is a professional responsibility (86\%). Physicians stated that they had no idea how to report ADRs with their current knowledge (81\%) and subject of pharmacovigilance was not well covered in the dental education (55\%). 86\% of them stated that education on this subject should be taken at undergraduate level (internship, education, clinical assignment) and $58 \%$ stated that it should be taken in their working life after graduation.

Conclusion: This study showed that the dentists participating in the study had a lack of awareness and knowledge about pharmacovigilance and ADR. It was observed that the rate of ADR reporting among physicians was very low compared to the encounter rate. Inclusion of pharmacovigilance in the educational program and providing pre- and post-graduate training to dentists for declaration practices can contribute positively to public health.
\end{abstract}

Key words: Adverse Drug Reaction, Drug Safety, Pharmacovigilance

DOI: 10.5798/dicletip.1023504

Correspondence / Yazıșma Adresi: Zeynep Erdogmus Ozgen, Department of Pharmacology, School of Pharmacy, Dicle University, Diyarbakir, Turkey e-mail: zeynep.erdogmus@dicle.edu.tr 


\section{Farmakovijilans ve Advers Etkilerin Raporlanması Üzerine Diş Hekimlerinin Görüşlerinin Araştırılması}

Öz

Amaç: Bu araştırma ile farmakovijilans paydaşlarından ilaç reçete etme ve kullanma oranı fazla olan diş hekimlerinin, advers (ters) ilaç etkileri ve farmakovijilans konusundaki deneyim, bilgi düzeyi ve farkındalıklarının incelenmesi amaçlandı.

Yöntemler: Kesitsel ve tanımlayıcı tipte yapılan bu çalışmada, Diyarbakır Ağız Diş Sağlığı Hastanesinde diş hekimi olarak görev yapan 100 hekime advers etkiler ve farmakovijilans ile ilgili deneyim, bilgi düzeyi ve farkındalıklarını değerlendirmek için 15 soruluk anket uygulandı.

Bulgular: Diş hekimlerinin \%55'i mesleki hayatlarında hiç advers ilaç reaksiyonu (ADR) ile karşılaşmadıklarını belirttiler. Yüzde 45'i meslek hayatlarında nadir olarak ADR gördüğünü bildirmiş olsa da toplam bildirim sayısı 7 olarak tespit edildi. Diş hekimlerinin \%78'i bildirim yapılması gerektiğini ve bu işlemin bir mesleki sorumluluk (\%86) olduğunun farkındadır. Hekimler mevcut bilgileri ile ADR'leri nasıl raporlayacakları hakkında bir fikirleri olmadığını (\%81) ve diş hekimliği müfredatında farmakovijilans konusunun iyi işlenmediğini (\%55) belirttiler. Bu konu ile ilgili eğitimin \%86 oranında lisans düzeyinde (staj, eğitim, klinik görevlendirme) ve \%58 oranında ise mezuniyet sonrası çalışma hayatında da alınması gerektiğini ifade ettiler.

Sonuç: Bu çalışma, araştırmaya katılan diş hekimlerinin farmakovijilans ve ADR konusunda farkındalık ve bilgi eksiklikleri olduğunu gösterdi. Hekimler arasında advers ilaç reaksiyonu bildirimi oranının karşılaşma oranına göre çok düşük olduğu görüldü. Eğitim programına farmakovijilans konusunun dahil edilmesi ve bildirim uygulamaları için diş hekimlerine mezuniyet öncesi ve sonrası eğitim verilmesi ile halk sağlığı açısından olumlu katkı sağlanabilir.

Anahtar kelimeler: Advers İlaç Reaksiyonları, Farmakovijilans, İlaç güvenliği.

\section{INTRODUCTION}

Adverse effects, which are defined as the harmful and unintended effects of a drug in the use of normal doses for the prevention, diagnosis, treatment of the disease or the modification of a physiological function, have a significant impact on public health ${ }^{1,2}$. Although reporting adverse drug reactions is a public health problem, it has been seen that not reporting these reactions increases the length of hospitalization by $5-20 \%$, which creates a financial burden on the health system $^{3}$. In addition, deaths due to advers drug reactions (ADR) were reported at a rate of $3,7 \%$ in studies. Therefore; detection, registration, and reporting of ADR are vital ${ }^{4}$. With pharmacovigilance, which is defined as the activities and scientific studies carried out to detect, evaluate, understand and prevent adverse reactions and other drug-related problems, safe use of drugs is ensured and the harm they may cause can be minimized.
The fact that the drug thalidomide, which was used in different parts of the world in 19611962 , caused birth defects in approximately 10 thousand children, brought the first efforts to address the issue of drug safety ${ }^{5}$. Following this disaster, a solution was adopted at the 16th World Health Congress (1963) that indicated the need for early action to systematically collect information on serious ADR during drug development and post-marketing. Pharmacovigilance term was first defined by the World Health Organization (WHO) in 1972 as 'any attempt to determine possible causal relationships between drugs in a particular population and the adverse effects of their use ${ }^{6}$. In 1978, the database, known as VigiBase, began to be managed by the Uppsala Monitoring Center (UMC). Members of the program submit reports of suspected adverse effects associated with drugs to the VigiBase system. The center then reviews and analyzes these international reports and shares the results with the member 
states ${ }^{7}$. It is very important to establish national pharmacovigilance systems as well as international collaborations. Within the scope of pharmacovigilance studies in Turkey, Turkish Adverse Effects Monitoring and Evaluation Center (TADMER) was established in 1985. Later in 2005, the name of the center was changed to Turkish Pharmacovigilance Center (TUFAM) ${ }^{8}$.

According to WHO standards, countries with good reporting rates give more than 200 declarations per 1 million people each year'. Based on this information, considering Turkey's population of 83 million, it is expected to make 16 thousand ADR declarations per year. On the other hand, only 2455 ADR were reported even in 2013, which is the highest number of reports with available data ${ }^{10}$. In addition, although regulations were published in 2014 to increase declarations in our country; the knowledge, attitudes and practices of healthcare professionals in Turkey regarding pharmacovigilance were found at very low levels in studies ${ }^{11,12}$. Adverse effects occur with oral symptoms such as dry mouth, oral ulcers, loss or change in taste, and swelling. For this reason dentists, who are among the pharmacovigilance stakeholders, have an important role in prescribing and using drugs. In the 200 most prescribed drugs, $80.5 \%$ dry mouth, $47.5 \%$ dysgeusia and $33.9 \%$ stomatitis were reported as adverse effects ${ }^{13}$. Therefore dentists have an important role in define and declaration these symptoms. With this study, it was aimed to investigate the experience, knowledge, and awareness of dentists on pharmacovigilance.

\section{METHOD}

This study was carried out with the approval of Health Sciences University Diyarbakır Gazi Yasargil Training and Research Hospital Clinical Research Ethics Committee dated 2021/07 and protocol number 829 . Our study, which was planned as research, was carried out with 100 volunteer physicians working as dentists in Diyarbakir Oral and Dental Health Hospital. The purpose of the research was explained to the physicians verbally by face-to-face interview technique and also briefly stated in writing at the beginning of the questionnaire. Informed consent forms were obtained from the physicians who agreed to participate in the study. The datas in the study were collected by applying a 15-question questionnaire with the technique of face-to-face interviews with physicians (Table I). The principles of the 'Helsinki Declaration' were complied with in the study. Each question in the questionnaire was evaluated in itself, and descriptive statistical analyzes such as frequencies and percentages were used to represent the demographic information of the participants through the SPSS 21 program.

\section{RESULTS}

In the study, 100 usable physician questionnaires were obtained. The survey questions consist of three parts. Part I; 1,1.1 and 1.2 questions are about encountering and reporting ADR in professional life and the attitudes of physicians towards these reactions. Part II; 2.-5. questions aimed at measuring ADR and pharmacovigilance knowledge levels, Part III; 6.-15. were assessment and evaluation questions aimed at increasing awareness in questions and identifying deficiencies in the current education system.

According to the results of the our study, when the demographic information of the physicians were examined, it was determined that $48 \%$ were female and $52 \%$ were male. Considering the professional experience of the physicians; it was observed that professional experience was declared as minimum 1 and maximum 30 years (average 11.06 years), while most of physicians had professional experience between 1-10 years (Table II). 
Table I: The survey questions consist of three groups. Part I: about encountering and reporting ADR in professional life and the attitudes of physicians towards these reactions. Part II: about measuring ADR and pharmacovigilance knowledge levels. Part III: about increasing awareness and identifying deficiencies in the current education system.

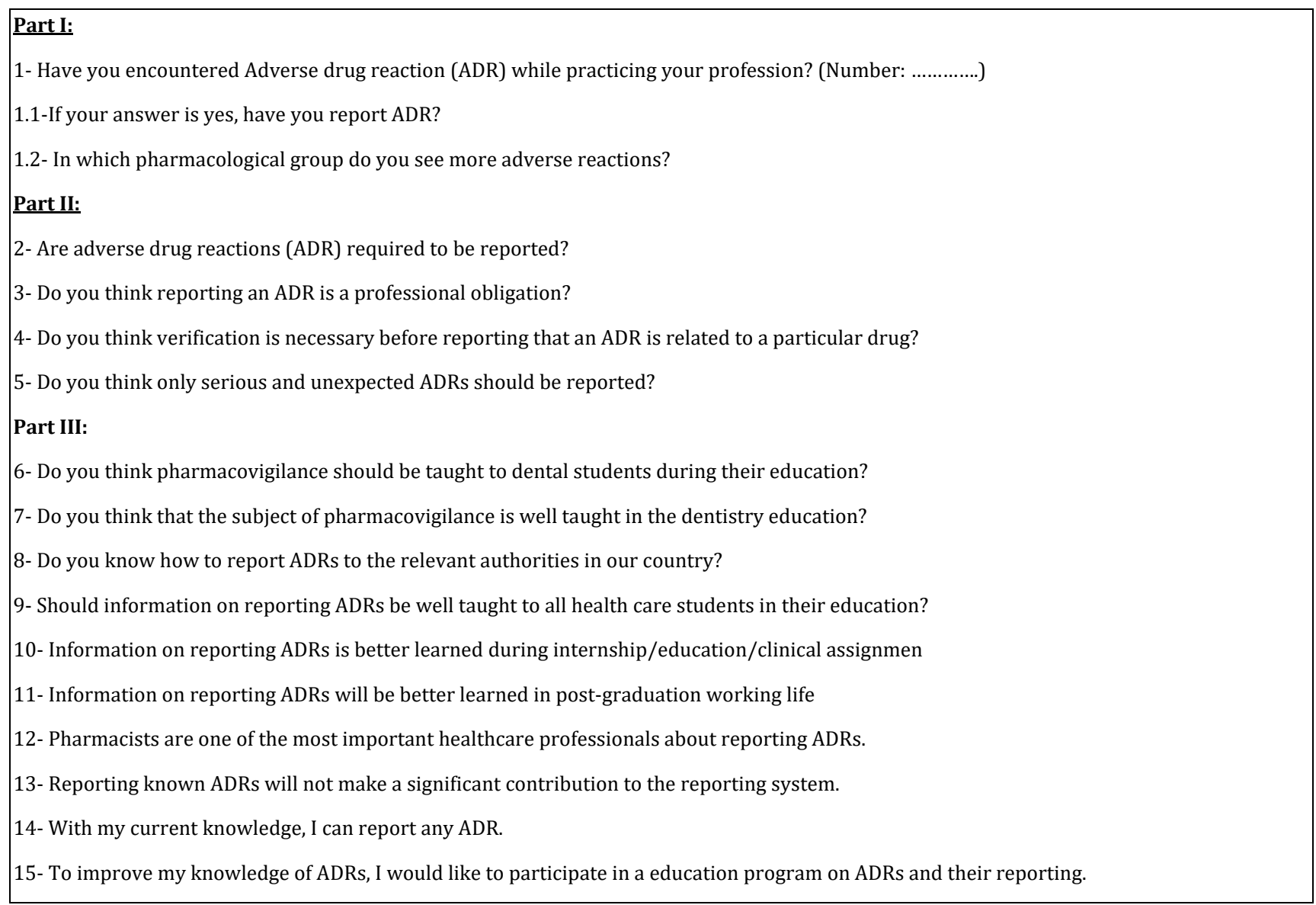

Table II: Professional experiences

\begin{tabular}{|l|l|}
\hline $\begin{array}{l}\text { Professional experince } \\
\text { (between year) }\end{array}$ & n (number of people) \\
\hline $1-5$ & 28 \\
\hline $6-10$ & 29 \\
\hline $11-15$ & 21 \\
\hline $16-20$ & 9 \\
\hline $21-25$ & 9 \\
\hline $26-30$ & 4 \\
\hline
\end{tabular}

$55 \%$ dentists stated that they have never encountered ADR in their professional life. Although 26\% reported that they encountered ADR with the highest rate rarely (and 19\% very rarely), it was found that only 7 ADR were reported to the relevant institutions (Table III). In the chi-square test conducted to investigate whether there is a relationship between encountering ADR and reporting, it was found that there was no relationship between them $(\mathrm{p}>$ 0.05) (Table IV). Of these 7 cases stated; it was observed that 4 of them were antibiotics, 1 of them was local anesthetic solution, 1 of them was analgesic mouthwash and the other one was analgesic.

Table III: ADR encounter rate

\begin{tabular}{|l|l|l|}
\hline ADR encounter & Percent (\%) \\
\hline \multirow{3}{*}{} & Rare & 26 \\
\cline { 2 - 3 } & Very Rare & 19 \\
\cline { 2 - 3 } & Non & 55 \\
\hline Total & 100,0 \\
\hline
\end{tabular}


Table IV: ADR encounter rates and reporting of ADRs.

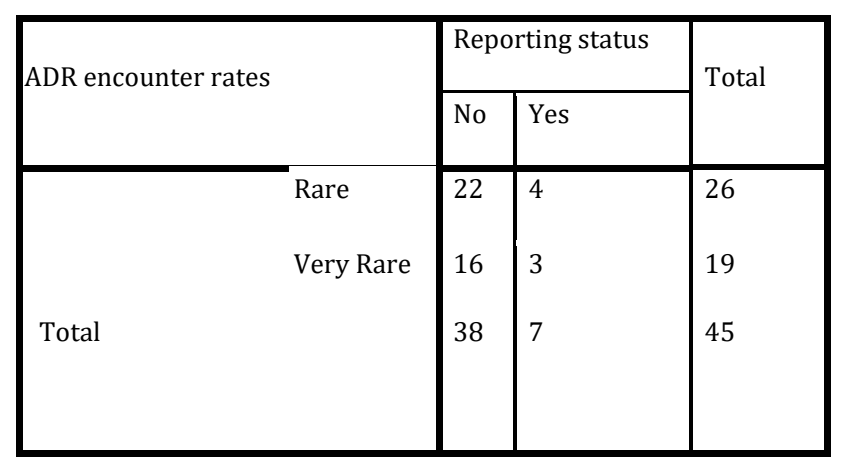

(relationship between encountering ADR and reporting; $p>0.05$ )

In another result of our study, although the reporting rate was so low, dentists also reported that $78 \%$ of the patients should be notified and this process is a professional responsibility (86\%). While awareness was high, dentists stated that only serious and unexpected ADR should be reported.

On the subject of pharmacovigilance, participants stated that they had no idea about how to report ADRs with their current knowledge (81\%) and that this subject was not handled well in the education of dental faculties (55\%). $86 \%$ of them stated that education on this subject should be taken at undergraduate level (internship, education, clinical assignment) and 58\% stated that it should be taken in their working life after graduation (Table V).

Table V: Effect of education on ADR report

\begin{tabular}{|l|l|}
\hline Questions & $\begin{array}{l}\text { Answer (Yes) } \\
\text { (percentage \%) }\end{array}$ \\
\hline $\begin{array}{l}\text { With my current knowledge, I can report any ADR. } \\
\text { pharmacovigilance is } \\
\text { well taught in the dentistry education? }\end{array}$ & 19 \\
\hline $\begin{array}{l}\text { Information on reporting ADRs is better learned } \\
\text { during internship/education/clinical assignmen }\end{array}$ & 86 \\
\hline $\begin{array}{l}\text { Information on reporting ADRs will be better } \\
\text { learned } \\
\text { in post-graduation working life }\end{array}$ & 58 \\
\hline
\end{tabular}

\section{DISCUSSION}

This study investigated the experience, knowledge, and awareness of dentists about ADR and pharmacovigilance. As a results of our study, the dentists participating in the survey agreed that reporting ADRs is a professional obligation (86\%). Although $45 \%$ of the participants stated that they had seen an ADR developing before, much less than that rate (15.55\%) was reported. In accordance with our results, in a study which made among dental research assistants by Karatas et al. ${ }^{14}$ emphasized that $90 \%$ of the ADR declaration was important, while they stated that the reporting rate was $0 \%$. In the survey conducted by Plaian et al., it was seen that the reporting rate was less than one-third, although it was found that ADR declaration was significant at the rate of $96.6 \% 15$. Arjun et al. emphasized that the rate of ADR declaration was 9\%, although they stated the importance of $72.53 \%{ }^{16}$. In a similar study conducted among pharmacists in Hong Kong, the requirement to report ADRs was $93 \%$, while the reporting rate remained at $14.7 \%{ }^{17}$. With these studies and literature reviews, it has been proven that awareness about ADR is high but the amount of reports are very low.

Another important issue we obtained in our study is the lack of knowledge of dentists on how to report the ADRs. According to our results, although $6 \%$ of participants stated that they could report, $32 \%$ stated that they had no idea and 26\% stated that they were insufficient. Similarly, Bishen et al. reported the level of reporting knowledge among the private dental practioners between $5-10 \%$ in their study ${ }^{18}$. Talattof and Azad also showed in their study that dentists have little knowledge about the importance, declaration and purpose of ADRs ${ }^{19}$. Shalini et al. reported that the level of knowledge is low, but awareness of ADR and pharmacovigilance is high in the study they conducted with dentistry students at a 
Malaysian university ${ }^{20}$. Khan et al. similarly, argued that the low rate of ADR reporting by dentists in hospitals was mainly due to a lack of knowledge and attitude ${ }^{21}$. Studies provide evidence that the education of health professionals can positively affect the underreporting rates of ADRs, and it is reported that more education and training are needed in this regard 22 . In many studies on pharmacovigilance in our country, similar to the results of our study, it is understood that health professionals (doctor, dentist, midwife/nurse and pharmacists) do not have sufficient knowledge about pharmacovigilance ${ }^{23-26}$. In our study, $80 \%$ of the dentists stated that both the compulsory pharmacovigilance course during the education period and the post-graduate inservice training programs will contribute to the development of the level of knowledge. The subject of pharmacovigilance should be taught to healthcare professionals through detailed and continuing education programs (83\%).

Dentists prescribe a variety of medications for oral and dental health. The most common medications routinely prescribed are analgesics, antibiotics, muscle relaxants, and the local anesthetics they commonly use. These drugs are known to cause various ADRs including tinnitus, anaphylactic shock, arrhythmia, ataxia and teratogenic effects, and headache in general. The mortality rate due to ADRs caused by the effect of these drugs was reported as $3.67 \% 27$. ADRs reported in our study were related to antibiotics, analgesic mouthwash and local anesthetic solution, respectively.

As a result, this study showed there is a lack of awareness and knowledge about pharmacovigilance and ADR among dentists. We believe that including pharmacovigilance in the training program and providing pre- and post-graduate training to dentists for declaration practices will contribute positively to public health.

\section{Acknowledgements}

All authors (ZEO, ZE) have participated in designing the study, drafting the manuscript, analysis, interpretation of the findings, revising the manuscript content and gave final approval of the final version of this manuscript.

Ethics Committee Approval: The study was approved by the Health Sciences University Diyarbakir Gazi Yasargil Training and Research Hospital Clinical Research Ethics Committee with protocol number (2021/829). All study participants gave written, informed consent to participate and for their deidentified data to be used in the publication.

Conflict of Interest:All of the authors of this manuscript declared that there is no conflict of interest.

Financial Disclosure: There are no financial supports.

\section{REFERENCES}

1. Kumar A. Pharmacovigilance: Importance, concepts, and processes. Am J Health Syst Pharm 2012; 74: 60612.

2. Edwards IR, Aronson JK. Adverse drug reactions: definitions, diagnosis, and management. The Lancet 2000; 356: 1255-9.

3. Kongkaew C, Noyce PR, Ashcroft DM. Hospital admissions associated with adverse drug reactions: a systemic review of prospective observationalstudies. The annals of pharmacotherapy 2008; 42: 1017-25.

4. Kulkarni MD, Baig MS, Chandaliya KC, et al. Knowledge, attitude and practice of pharmacovigilance among prescribers of government medical college and hospital, Aurangabad (Maharashtra). Int J Pharm Ther 2013; 3:10-8.

5. Caduff-Janosa P. Lost in regulation. Pharmacovigilance. Springer 2017; 9-19.

6. World Health Organization. Pharmacovigilance (cited 2019); Available from: https://www.who.int/medicines/areas/quality_safet y/safety_efficacy/pharmvigi/en/.

7. The Uppsala Monitoring Center. The story of UMC and the WHO Programme 2018 (cited 02 Şubat 2018). 
Available from: https://www.who-umc.org/globalpharmacovigilance/who-programme/the-story-ofumc-and-the-who-programme/.

8. TUFAM activities, Available from: https://www.titck.gov.tr/faaliyetalanlari/ilac/18

(Access date: 1 Sep 2021).

9. World Health Organization. Safety monitoring of medicinal products: guidelines for setting up and running a pharmacovigilance centre. World Health Organization and the Uppsala Monitoring Centre, Available online: www who-umc org/graphics/4807 pdf. 2000.

10. Ozcan G, Aykac E, Kasap Y, et al. Adverse drug reaction reporting pattern in Turkey: analysis of the national database in the context of the first pharmacovigilance legislation. Drugs-Real World Outcomes 2016; 3: 33-43.

11. Alan S, Öztürk M, Gökyıldız S, et al. An evaluation of knowledge of pharmacovigilance among nurses and midwives in Turkey. Indian J Pharmacol 2013; 45: 6168.

12. Vural F, Ciftçi S, Vural B. The knowledge, attitude and behaviours of nurses about pharmacovigilance, adverse drug reaction and adverse event reporting in a state hospital. NortClin Istanbul 2014; 1: 147-52.

13. Smith RG, Burtner AP. Oral side-effects of the most frequently prescribed drugs. Spec Care Dentist 1994; 14: 96-102. DOI: 10.1111/ j.17544505.1994.tb01112.x.

14. Karataş Y, Khan Z, Ozagil EZ, et al. Knowledge, attitude and practices about pharmacovigilance. J Health Sci Med 2020; 3: 367-71.

15. Palaian S, Ibrahim MI, Mishra P. Health professionals' knowledge, attitude and practices towards pharmacovigilance in Nepal. Pharmcy practice 2011; 9: 228-35.

16. Arjun TN, Sudhir H, Gouraha A, et al. Assessment of knowledge, attitude and practice related to pharmacovigilance among the healthcare professionals in a teaching hospital in central India: An questionnaire study. World J Pharm Sci 2015; 4: 78599.

17. Lee KK, Chan TY, Raymond K, et al. Pharmacists' attitudes toward adverse drug reaction reporting in Hong Kong. Ann Pharmacother 1994; 28: 1400-3.
18. Bishen KA, Anil B, Madhusudan A, et al. A study on knowledge, attitude and practices of private dental practioners regarding pharmacovigilance and adverse drug reaction reporting in Jodhpur City, India. European Journal of Biomedical 2018, 5: 652-7.

19. Talattof Z, Azad A. An evaluation of knowledge, attitude and practice of adverse drug reaction reporting in dental practice. Pak J Nutr 2015; 14: 7125. DOI: $10.3923 /$ pjn.2015.712.715.

20. Shalini S, Mohan S. Knowledge and attitude towards pharmacovigilance and adverse drug reaction reporting among dental students in a private university, Malaysia. J Young Pharm 2015; 7: 118-25. DOI: 10.5530/jyp.2015.2.10.

21. Khan SA, Goyal C, Tonpay SD. A study of knowledge, attitudes, and practice of dental doctors about adverse drug reaction reporting in a teaching hospital in India. Perspect Clin Res 2015; 6: 144-9. DOI:10.4103/22293485.159938.

22. Campbell JE, Gossell-Williams M, Lee MG. A Review of Pharmacovigilance. West Indian Med J 2014; 63: 771.

23. Ergün Y, Ergün TB, Toker E, et al. Knowledge attitude and practice of Turkish health professionals towards pharmacovigilance in a university hospital. International Health 2019; 11: 177-84.

24. Ozcan G, Aykac E, Kasap Y, et al. Adverse drug reaction reporting pattern in Turkey: Analysis of the national database in the context of the first pharmacovigilance legislation. Drugs-real world outcomes 2016; 3: 33-43.

25. Toklu HZ, Uysal MK. The knowledge and attitude of the Turkish community pharmacists toward pharmacovigilance in the Kadikoy district of Istanbul. Pharm World Sci 2008; 30: 556-62.

26. Toklu HZ, Soyalan M, Gultekin 0, et al. The knowledge and attitude of the healthcare professionals towards pharmacovigilance and adverse drug reaction reporting in northern Cyprus. J Pharmacovigilance 2016; 4: 1-7.

27. Kulkarni MD, Baig MS, Chandaliya KC, et al. Knowledge, attitude and practice of pharmacovigilance among prescribers of Government medical college and hospital, Aurangabad (Maharashtra). Int J Pharm Ther 2013; 3: 10-8. 